\title{
Molecular basis of quorum sensing signal-response systems in bacteria
}

\author{
AliCJA ZIEMICHÓd, ${ }^{1}$ BOGUMIŁA SKOTARCZAK ${ }^{2}$ \\ University of Szczecin, Department of Genetics, Faculty of Biology, Felczaka 3c, 71-412 Szczecin, Poland \\ 1 e-mail: genetyka@univ.szczecin.pl \\ 2 e-mail: boskot@univ.szczecin.pl
}

Keywords

autoinducers 2 and 3, QS phenomenon, quinolone signal molecules, signal molecules of Grampositive and Gram-negative bacteria

Abstract Bacteria use quorum sensing (QS) to conduct gene expression programmes connected with collective behaviors. $Q S$ indicates on the capacity of bacteria to monitor their population density and regulate gene expression. $Q S$ activates from tens to hundreds of genes that underlie different biological processes. The $Q S$-regulated processes organize horizontal gene transfer, the formation of biofilms, multicellular behaviors, microbe-host and microbe-microbe relations. The $Q S$ signaling requires the production, release, detection, exchange and perception of bacterial compounds, known as autoinducers or $Q S$ signals. Recently, new autoinducers have been discovered in bacteria and it has been shown how these molecules are recognized by the respective receptors. Autoinducers belong to three major classes: acyl-homoserine lactones (AHLs) used by Gram-negative bacteria, specific oligopeptides used by Gram-positive bacteria and universal autoinducers. The aim of this paper is to provide an overview of molecular basis of the $Q S$ phenomenon, characterization of intra- and interspecies $Q S$ signaling molecules and biological processes regulated by these molecules.

\section{Molekularne podstawy quorum sensing systemów odpowiedzi sygnałowej u bakterii}

Słowa kluczowe autoinduktory 2 i 3, chinolonowe cząsteczki sygnałowe, cząsteczki sygnałowe bakterii Gramdodatnich i Gram-ujemnych, zjawisko $Q S$

Streszczenie Bakterie używają quorum sensing (QS) do przeprowadzania programów ekspresji genów związanych z zachowaniami grupowymi. $Q S$ oznacza zdolność bakterii do monitorowania gęstości swojej populacji i regulacji ekspresji genów. $Q S$ aktywuje od dziesiątek do setek genów, które są związane z różnymi procesami biologicznymi. Procesy regulowane przez $Q S$ są związane z horyzontalnym przepływem genów, tworzeniem biofilmów, zachowań wielokomórkowych, oraz relacji bakteria-żywiciel i bakteria-bakteria. Sygnalizacja $Q S$ wymaga wytwarzania, uwalniania, wykrywania, wymiany i percepcji komponentów nazywanych autoinduktorami lub sygnałami $Q S$. Ostatnio u bakterii zostały odkryte nowe autoinduktory oraz wykazano jak te cząsteczki są rozpoznawane przez odpowiednie receptory. Autoinduktory należą do trzech głównych klas: do acylowanych laktonów homoseryny (AHLs) używanych przez bakterie Gram-ujemne, specyficznych oligopeptydów używanych przez bakterie Gram dodatnie i do 
autoinduktorów uniwersalnych. Celem artykułu jest przegląd bazy molekularnej zjawiska $Q S$, w tym wewnątrz i międzygatunkowych cząsteczek sygnałowych $Q S$ oraz procesów biologicznych regulowanych przez te cząsteczki.

\section{Introduction}

Successful survival in nature of all organisms is dependent on their ability of perception and adaptation to the surrounding environment. Bacteria spread throughout the natural world, inhabit a variety of ecosystems - from the thermal springs to the highly acidic environment of the human stomach. An indispensable component of a successful colonization and exploitation of such niches is the ability of microorganisms to sense the environment and the appropriate modification of their behavior, which will allow them to survive under certain conditions (Pereira et al., 2013). Adaptation of microorganisms to the prevailing conditions results from their interrelationships through a complex network of signaling pathways which activation leads to changes in bacterial gene expression and generate optimal phenotypes under certain conditions (Pereira et al., 2013).

The discovery of the phenomenon of $Q S$, otherwise called as phenomenon of sensing the amount by Nealson and Hastings, announced a revolution in the field of microbiology, transforming current thinking about microorganisms (O'Toole, 2016). This discovery was a huge surprise to many researchers, who believed for a long time that such action is limited only to multicellular organisms (Li, Tian, 2012), and microorganisms in contrast to higher organisms do not have any system to enable them "smart" communication with each other (Matejczyk, Suchowierska, 2011).

In the mechanism of $Q S$, bacteria communicate with each other through generated by themselves and excreted to the external environment chemical, relaying signals called autoinducers (Suárez-Moreno et al., 2010). The concentration of signaling molecules in the environment is strictly correlated with the density of a growing population of bacteria, so that the response of individual cells is dependent on the behavior of the entire living population in a particular niche (Suárez-Moreno et al., 2010). In practice, the system is used by the bacteria to activate processes which would be ineffective in the case of acting alone, for example in biofilm formation (Bassler, Losick, 2006). In short, the molecular mechanism of this phenomenon is based on the production of signaling compounds by cells, their accumulation in the environment of bacterial growth, then the recognition of produced signals by specific receptor proteins acting as sensors of the signal, and in consequence, coordinated, global response of cells to these signals, resulting in a change in the expression of genes that control essential metabolic pathways and processes of life (Jaworski et al., 2005).

There are four functional groups among the genes that control the QS (Grandclement et al., 2016). The first group includes genes encoding proteins involved in the basic life functions, the second one includes genes related to the behavior of cells in a given environment, in the third group there are genes which subject to a horizontal transfer, and in the fourth one - genes that encode proteins that enable interaction with other organisms, e.g. proteins associated with virulence.

The term " $Q S$ " comes from the Latin word "quorum" which means the number of votes that must be cast during the election or referendum, so that the election was considered as valid (ScienceDaily, 2009). It is believed that the transfer of this concept on the microbiological grounds best captures the essence of sensing mechanism of the number of bacteria.

In microbiology this term is defined as a process in which the bacterial cells detect the minimum, threshold concentration of signaling molecules in the external environment and then 
after exceeding the allowable minimum, they respond accordingly and modify their behavior by altering the expression of their genes (Bassler, Losick, 2006).

A wide range of biological processes is regulated through the mechanism of $Q S$, such as: bioluminescence, mobility, synthesis of virulence factors, competence, horizontal gene transfer, biofilm formation, production of antibiotics or swariming growth (Lixa, 2015).

The phenomenon of $Q S$ has been discovered in different species of bacteria, but similar systems have been also reported in the case of other organisms (Suárez-Moreno et al., 2010). It should be noted that the various sensing systems of bacteria are very similar to each other, which is due to the fact that the ability of intercellular communication is common in the world of bacteria, because it increases the chance of survival in a specific environment. However, types of chemical signals, their receptors, mechanism of signal transmission and purpose of each system of $Q S$ show the uniqueness for each species of bacteria (Papenfort, Bassler, 2016).

\section{Autoinducers of QS}

Intercellular communication of microbes is based on the synthesis, secretion and response to small diffusive signaling molecules called autoinducers, which are signalers of cell density (Jamuna Bai, Ravishankar Rai, 2011). Their concentration in the environment for bacterial growth is closely correlated to the number of bacterial cells. These compounds are secreted and released into the environment either by diffusion or by active transport. After reaching a certain concentration of signaling molecules, it comes to the induction of the expression of certain genes under the control of QS system (Baranowska, Rodziewicz, 2008), and as a consequence to simultaneous metabolic changes in all cells of the population (Kołwzan, 2011). According to Wizner et al. (2002), diffusive signaling molecules have some characteristic features that distinguish them from secondary metabolites. The four basic criteria that must be fulfilled by a molecule so that it is recognized as autoinducer by $Q S$ system are:

1. Production of this molecule must occur at specific stages of growth of the population in certain physiological conditions or in response to environmental changes.

2. Such compound should be accumulated extracellularly and recognized by specific receptors.

3. The accumulation of such molecules should generate a coordinated response of all cells of the population after reaching a certain critical threshold concentration.

4. The cell response of the population should go beyond the metabolic and physiological changes which comprise only the use of this compound as a source of carbon and energy.

Chemical structure of autoinducers and mechanism of their action is different, according to the species of the microorganism (Kołwzan, 2011). Most often, the examined autoinducers belong to one of three classes: acyl-homoserine lactones (AHLs) used by Gram-negative bacteria, specific oligopeptides used by Gram-positive bacteria and universal autoinducers (autoinducers-2) used by both gram-negative and gram- positive bacteria (LaSarre, Federle, 2013). However, it should be noted that there are also other signaling molecules of $Q S$ system not belonging to any of these classes and these include quinolone molecules used by Pseudomonas aeruginosa (PQS) or autoinducer-3 (AI-3). There is no doubt that the new signal molecules will be discovered at the time when the studies on $Q S$ are expanded with bacterial species which have been unexplored yet (LaSarre, Federle, 2013). The previous observations of phenomenon of communication among microorganisms have shown that bacteria are capable to send both specific communication signals 
within their own species, and non-specific, among different species (Matejczyk, Suchowierska, 2011).

\section{Signal molecules of Gram-negative bacteria}

The four common features are found in almost all known $Q S$ systems in Gram-negative bacteria (Ng, Bassler, 2009). Firstly, autoinducers in such systems are mentioned above acyl-homoserine lactones (AHLs) or other molecules which are synthesized from S-adenosylmethionine (SAM), and they are able to diffuse freely through the bacterial membrane. Secondly, autoinducers are associated with specific receptors, which are located both in the inner membrane and in the cytoplasm. Thirdly, $Q S$ usually activates from tens to hundreds of genes that underlie different biological processes. Fourthly, in a process called autoinduction, activation of $Q S$, led by autoinducers stimulates the increased synthesis of autoinducers, which establishes the so-called feed-forward loop which supports synchronous expression of genes in the population. The feedforward loop is a common motif in the regulatory network of biological pathways. The loop is composed of two factors (usually the regulators of transcription), one regulates the other so that both of these factors together regulate target genes. The recent studies on $Q S$ in Gram-negative bacteria have demonstrated the existence of new autoinducers in these bacteria and have shown how these molecules are recognized by the respective receptors; new regulatory elements have been also revealed, which are included in the basic signaling circuits, and there have been identified new regulatory networks (Papenfort, Bassler, 2016).

Gram-negative bacteria often use several autoinducers, and new studies reveal the molecular determinants that provide a unique receptor specificity in distinguishing closely related molecules. The QS information is often integrated by small RNA molecules (sRNAs) (Papenfort, Vogel, 2010) that control the expression of target genes, and also act in feedback loops. The network architecture of $Q S$ supports the accuracy of signaling, time control and flexible dynamics of flows.

As mentioned above, the role of signal molecules in Gram-negative bacteria play acylhomoserine lactones (AHLs) (Gera, Srivastava, 2006). A common feature of all AHLs, also referred as type 1 autoinducers (AI-1) is a lactone ring of homoserine. The difference in the chemical structure of each of the homoserine lactones in different bacteria species concerns the side acyl substituent. Various substituents may have different length depending on the number of carbon atoms in chain and may differ in further modifications (Siepka, Gładkowski, 2012). Additionally, it was found that a significant number of AHLs molecules synthesized by Gramnegative bacteria include an even number of carbon atoms in their side chain (Gera, Srivastava, 2006). Differences in the structure of the side chain give each AHL molecule unique specifications by which each species of bacteria has its own, characteristic for each other "language of communication" incomprehensible for other species (Federle, Bassler, 2003). Depending on the length of the acyl chain, transport of the AHL through the membrane and cell wall to the external environment may take place without energy input, in a passive way based on the phenomenon of diffusion (autoinducers having substituents with short chains), or with the involvement of energy by active transport (long-chain AHLs) (Siepka, Gładkowski, 2012).

As substrates for the production of signaling molecules, Gram-negative bacteria use S-adenosylmethionine (SAM) and acyl group being the product of transformation of fatty acids (Baranowska, Rodziewicz, 2008). Transfer of the acyl group on the lactone molecule is performed by the carrier protein, ACP (acyl carrier protein) (Kołwzan, 2011). The role of LuxI protein in the autoinducer synthesis covers only connection of SAM with the specific for the bacteria species 
ACP by formation of amide linkage (Waters, Bassler, 2005). Then comes to the formation of an ester linkage in the homoserine molecule and as a result of those reactions, 5'-methylthioadenosine product occurs, and after its disconnection, the finished AHL is formed (Czajkowski, Jafra, 2006).

\section{Signal molecules of Gram-positive bacteria}

In the evolution process, Gram-positive bacteria have developed different processes of synthesis of signal molecules as well as methods of transmitting signals from the sensor proteins of a cell to the effectors. Mechanisms and proteins involved in $Q S$ in Gram-positive bacteria are best known in Streptococcus pneumoniae, Bacillus subtilis and Staphylococcus aureus (Grossman, 1995). Systems of gram-positive bacteria normally use secreted oligopeptides and two-component systems, consisting of receptors for a sensor kinase associated with membrane and cytoplasmic transcription factors that determine changes in gene expression (Novick, Geisinger, 2008).

Gram-positive bacteria, in contrast to Gram-negative ones do not produce AHLs, and as signaling molecules, essential for intercellular communication use oligopeptide autoinducers AIPs (autoinducing peptides) (Kołodyński, Jankowski, 2005). The AIPs result from digestion of larger protein precursors (Kołwzan, 2011). They consist of 5-17 amino acids and modified side chains (Siepka, Gładkowski, 2012). A large part of Gram-positive bacteria belonging to phylum Firmicutes use thiolactone/lactone peptides as AIPs communication signals to coordinate $Q S$ circuit. In particular, $Q S$ of staphylococci, enterococci, and clostridia have been intensively examined in terms of alternative target of anti-pathogenic therapy independent of bactericidal antibiotics (Singh et al., 2016). Unlike AHLs, signaling oligopeptides of Gram-positive bacteria are not able to diffuse freely through the cell membrane (Kołwzan, 2011). They are produced in the cytoplasm in the form of precursors and they are modified and separated from the cell (Siepka, Gładkowski, 2012) with the participation of ABC transporting protein, dependent from ATP (ATP - binding cassete) (Jaworski et al., 2005).

\section{Autoinducers-2}

It has not been established yet why Gram-negative bacteria use acylated homoserine lactones as signaling molecules, while Gram-positive ones - oligopeptide autoinducers (Kołodyński, Jankowski, 2005). The use of various autoinducers and communication mechanisms results probably from different construction of their cell walls (Matejczyk, Suchowierska, 2011). However, it has been proved that both groups of bacteria are capable to produce molecules non-specific for any species. It means that with the help of these autoinducers, called autoinducers-2 (AI-2) or universal autoinducers, the microorganisms may communicate interspeciesly (Sztajer et al., 2008). The discovery of AI-2, by which different species and types of bacteria can communicate with each other, was a breakthrough in research on $Q S$ system and allowed for a better knowing and understanding of interactions between microorganisms in the environment. Chemical structure and biosynthesis of these autoinducers is described in further part of this paper.

\section{Quinolone signal molecules}

As mentioned before, except the three main categories of autoinducers, there are also other signaling molecules, which are not included in any of the above classes (LaSarre, Federle, 2013). 
The quinolone molecules are examples of such autoinducers, used by Pseudomonas aeruginosa in the intercellular communication (Pseudomonas quinolone signal molecule - PQS) (Myszka, Czaczyk, 2010). 3,4-dihydroxy-2-heptylquinoline (PQS) and its precursor 4-hydroxy-2-heptylquinoline (HHQ) are the products of expression of the operon pqsABCDE. Both molecules act as autoinducers of $Q S$ system and the only difference in their chemical structure is the presence of an additional hydroxy group located in the 3' position of PQS. Although only P. aeruginosa produces PQS, other species of Pseudomonas and Burholderia spp. may use HHQ as a $Q S$ signal (LaSarre, Federle, 2013).

\section{Autoinducer-3}

Autoinducer-3 (AI-3) is the least known signal molecule of $Q S$ system. AI-3 is produced by the commensal bacteria constituting the physiological intestinal microflora of humans as well as certain species of intestinal pathogens. The molecular structure of this molecule or gene responsible for its synthesis have not been known so far (LaSarre, Federle, 2013). In enterohemorrhagic strain of Escherichia coli (EHEC), mechanism of communication with the use of AI-3 is responsible among other things for the regulation of motility or activation of transcription of genes involved in virulence (Kendall, Sperandio, 2014). But in enteropathogenic E. coli (EPEC), this system is related in part to the formation of biofilm, because it controls the expression of the protein EspA, which is involved in the creation of micro-colonies in the initial phase of development of the biofilm of this strain (Kendall, Sperandio, 2014). AI-3 molecule is recognized by a protein kinase QseC, which due to autophosphorylation, initiates a cascade of reactions leading to the phosphorylation of the regulator of QseB response and in consequence, to activation of transcription of target genes. Because the same two-component regulatory system $\mathrm{QseC} / \mathrm{B}$ is also used for the detection of adrenaline and noradrenaline, it is believed that AI-3 is structurally similar to these hormones (LaSarre, Federle, 2013). This is confirmed by the fact that the effects induced by AI-3 may be inhibited by antagonists of adrenergic receptors (Kendall, Sperandio, 2014).

\section{Conclusions}

Diffusion chemical communication among bacteria through $Q S$ is a central system of bacteria's life that facilitates bacteria to recognise synergistic or antagonistic population in environment and enables them to control collective behaviors. Synthesis of $Q S$ modulators is being dynamically pursued to modify bacterial behavior on request. These and other new research raise our knowledge about the bacterial $Q S$ networks which enable them to survive and actively colonize new ecological niches and increase their expansion using new nutrient substrates.

\section{References}

Baranowska, K., Rodziewicz, A. (2008). Molekularne interakcje w biofilmach bakteryjnych. Kosmos, 1-2 (57), 29-38.

Bassler, B.L., Losick, R. (2006). Bacterially speaking. Cell, 125, 237-246.

Czajkowski, R., Jafra, S. (2006). Enzymatyczna degradacja laktonów acylo-L-homoseryny i jej potencjalne wykorzystanie w biokontroli i hamowaniu rozwoju infekcji. Biotechnologia, 2, 49-64. 
Federle, M.J., Bassler, B.L. (2003). Interspecies communication in bacteria. Journal of Clinical Investigation, 112, 1291-1299.

Gera, C., Srivastava, S. (2006). Quorum sensing: The phenomenon of microbial communication. Current Science, 90, 666-677.

Grandclément, C., Tannières, M., Moréra, S., Dessaux, Y., Faure, D. (2016). Quorum quenching: role in nature and applied developments. FEMS Microbiology Reviews, 1 (40), 86-116.

Grossman, A.D. (1995). Genetic networks controlling the initiation of sporulation and the development of genetic competence in Bacillus subtilis. Annual Review of Genetics, 29, 477-508.

Jamuna Bai, A., Ravishankar Rai, V. (2011). Bacterial quorum sensing and food industry. Comprehensive Reviews in Food Science and Food Safety, 10, 184-194.

Jaworski, A., Serwecińska, L., Stączek, P. (2005). Quorum sensing - komunikowanie się komórek w populacjach bakterii przy udziale chemicznych cząsteczek sygnałowych. Postępy Biologii Komórki, 32, 231-256.

Kendall, M.M., Sperandio, V. (2014). Cell-to-cell signaling in E. coli and Salmonella. EcoSal Plus, 1 (6).

Kołodyński, J., Jankowski, S. (2005). Systemy międzykomórkowej sygnalizacji u bakterii. Advances in Clinical and Experimental Medicine, 14, 343-348.

Kołwzan, B. (2011). Analiza zjawiska biofilmu - warunki jego powstawania i funkcjonowania. Ochrona Środowiska, 4 (33), 3-14.

LaSarre, B., Federle, M.J. (2013). Exploiting quorum sensing to confuse bacterial pathogens. Microbiology and Molecular Biology Reviews, 1 (77), 73-111.

Li, YH., Tian, X. (2012). Quorum sensing and bacterial social interactions in biofilms. Sensors, 12, 25192538.

Lixa, C., Mujo, A., Anobom, C.D., Pinheiro, A.S. (2015). A structural perspective on the mechanisms of quorum sensing activation in bacteria. Annals of the Brazilian Academy of Sciences, 4 (87), 21892203.

Matejczyk, M., Suchowierska, M. (2011). Charakterystyka zjawiska quorum sensing i jego znaczenie w aspekcie formowania i funkcjonowania biofilmu w inżynierii środowiska, budownictwie, medycynie oraz gospodarstwie domowym. Budownictwo i Inżynieria Środowiska, 2, 71-75.

Myszka, K., Czaczyk, K. (2010). Mechanizm quorum sensing jako czynnik regulujący wirulencję bakterii Gram-ujemnych. Postępy Higieny i Medycyny Doświadczalnej, 64, 582-589.

Ng, W.L., Bassler, B.L. (2009). Bacterial quorum-sensing network architectures. Annual Review of Genetics, 43, 197-222.

Novick, R.P., Geisinger, E. (2008). Quorum sensing in staphylococci. Annual Review of Genetics, 42, 541564.

O'Toole, G.A. (2016). Classic spotlight: quorum sensing and the multicellular life of unicellular organisms. Journal of Bacteriology, 4 (198), 601.

Papenfort, K., Bassler, B.L. (2016). Quorum sensing signal-response systems in Gram-negative bacteria. Nature Reviews Microbiology, 9 (14), 576-588.

Papenfort, K., Vogel, J. (2010). Regulatory RNA in bacterial pathogens. Cell Host Microbe, 1 (8), 116-127.

Pereira, C.S., Thompson, J.A., Xavier, K.B. (2013). AI-2-mediated signalling in bacteria. FEMS Microbiology Reviews, 37, 156-181.

ScienceDaily (2009). Bacterial quorum sensing: a matter of density, not quantity. Retrieved from: https:// www.sciencedaily.com/releases/2009/07/090710101452.htm.

Siepka, M., Gładkowski, W. (2012). Zjawisko quorum sensing. Nowe trendy w naukach przyrodniczych, tom III. Kraków: CreativeTime. 
Singh, R.P., Desouky, S.E., Nakayama, J. (2016). Quorum quenching strategy targeting Gram-positive pathogenic bacteria. Advances in Experimental Medicine and Biology, 901, 109-130.

Suárez-Moreno, Z.R., Kerényi, Á., Pongor, S., Venturi, V. (2010). Multispecies microbial communities. Part I: quorum sensing signaling in bacterial and mixed bacterial-fungal communities. Mikologia Lekarska, 2 (17), 108-112.

Sztajer, H., Lemme, A., Vilchez, R., Schulz, S., Geffers, R., Ying Yin Yip, C., Levesque, C.M., Cvitkovitch, D.G., Wagner-Döbler, I. (2008). Autoinducer-2-regulated genes in Streptococcus mutans UA159 and global metabolic effect of the luxS mutation. Journal of Bacteriology, 1 (190), 401-415.

Waters, C.M., Bassler, B.L. (2005). Quorum sensing: cell-to-cell communication in bacteria. Annual Review of Cell and Developmental Biology, 21, 319-346.

Wizner, K., Hardie, K.R., Williams, P. (2002). Bacterial cell-to-cell communication: sorry, can't talk now - gone to lunch! Current Opinion in Microbiology, 5, 216-222.

Cite as: Ziemichód, A., Skotarczak, B. (2017). Molecular basis of quorum sensing signal-response systems in bacteria. Acta Biologica, 24, 133-140. DOI: 10.18276/ab.2017.24-11. 